University of Nebraska - Lincoln

DigitalCommons@University of Nebraska - Lincoln

Papers in the Earth and Atmospheric Sciences

Earth and Atmospheric Sciences, Department

2017

\title{
Crustal distribution in the central Gulf of Mexico from an integrated geophysical analysis
}

Irina Filina

University of Nebraska - Lincoln, ifilina2@unl.edu

Follow this and additional works at: https://digitalcommons.unl.edu/geosciencefacpub

Part of the Earth Sciences Commons

Filina, Irina, "Crustal distribution in the central Gulf of Mexico from an integrated geophysical analysis" (2017). Papers in the Earth and Atmospheric Sciences. 674.

https://digitalcommons.unl.edu/geosciencefacpub/674

This Article is brought to you for free and open access by the Earth and Atmospheric Sciences, Department of at DigitalCommons@University of Nebraska - Lincoln. It has been accepted for inclusion in Papers in the Earth and Atmospheric Sciences by an authorized administrator of DigitalCommons@University of Nebraska - Lincoln. 


\section{Crustal distribution in the central Gulf of Mexico from an integrated geophysical analysis Irina Filina*, the University of Nebraska at Lincoln}

\section{Summary}

This study addresses the question of the crustal composition in the central part of the northern Gulf of Mexico (GOM) the region of the major disagreement between published tectonic models. The location of the Ocean-Continental Boundary (OCB) for different tectonic models varies within $140 \mathrm{~km}(87 \mathrm{mi})$ in the study area. I have developed a 2D model integrating the seismic reflection and refraction data with potential fields (gravity and magnetics) along the profile through the debated region. Two alternative OCB locations were tested. The preferred model suggests the OCB position near the Sigsbee Escarpment, which is in agreement with the result of Eddy, 2014 and with the findings of the LithoSPAN experiment (Makris et al, 2015). However, the model with an alternative OCB location (further to the north of the Sigsbee Escarpment) may also satisfy the observed gravity and magnetic fields, although the crust in the oceanic domain is thicker than normal. Since

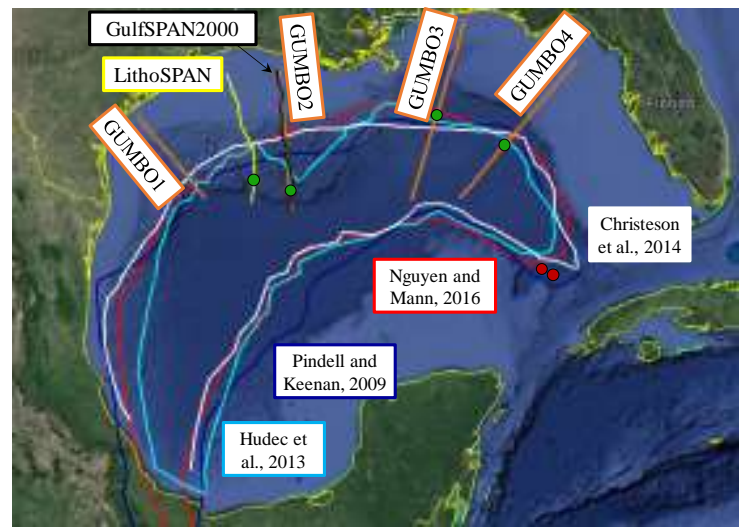

Figure 1: Google Map screenshot of the Gulf of Mexico. The Ocean-Continent Boundary (OCB) locations from several recent tectonic models are shown (dark blue - Pindell and Keenan, 2009, light blue - Hudec et al., 2013, white - Christeson et al., 2014, red - Nguyen and Mann, 2016). Two red circles show the DSDP drill sites from Leg 77 that penetrated basement and confirmed the presence of continental crust. The orange profiles are four refraction lines from the GUMBO experiment; the GUMBO 2 (Eddy, 2014) was used in this study. Seismic reflection profile GulfSPAN 2000 (Radovich et al., 2011) is shown as a black line, and the LithoSPAN refraction profile (Makris et al., 2015) is a yellow line.

Green circles show the approximate location of the OCB along the LithoSPAN (Makris et al., 2015), the preferred OCB position from this study along GUMBO 2 (coincident with interpretation of Eddy, 2014), the interpreted OCB for GUMBO3 from Eddy, 2014 and for GUMBO4 from Christeson et al., 2014. the potential fields do not offer the unique answer, the other geophysical data should be examined, such as the $\mathrm{Vp} / \mathrm{Vs}$ ratio. This parameter was analyzed for the LithoSPAN (Makris et al., 2015) and allowed distinguishing between continental and oceanic domains; it was also examined for GUMBO 3 and 4 (Duncan, 2013). However, the values of $\mathrm{Vs}$ derived during retraction experiment for GUMBO 2 are not publically available at this time.

\section{Introduction}

The Gulf of Mexico (GOM) comprises one of the most prolific petroleum regions in the world (Whaley, 2006, Dribus, 2008). The basin developed during the break-up of the super-continent Pangea (Pindell and Keenan, 2009, Kneller and Johnson, 2011, Hudec et al., 2013, Christeson et al., 2014, Nguyen and Mann, 2016). The tectonic models of the GOM generally agree on the fact that the basin formation started in Late Triassic as a northwest-southeast continental rift, followed by Jurassic drifting phase, when the Yucatan crustal block rotated counterclockwise leaving behind the curved pattern of the oceanic basin. However, the location of the Ocean-Continental Boundary (OCB) is still being debated, as illustrated in Figure 1. The major discrepancy between the published tectonic models is found in the central part of the northern Gulf of Mexico. The variation in the OCB locations in this area reaches $140 \mathrm{~km}(87 \mathrm{mi})$. The major objective of this study is to analyze all publically available geological and geophysical data to investigate the nature of the crust in the central GOM.

The datasets used for this analysis include Free-Air gravity data (Sandwell et al., 2014), magnetic data (Bankey et al, 2002), reflection seismic line GulfSPAN 2000 (Radovich at al., 2011, Figure 2a), refraction line GUMBO 2 (Eddy, 2014, Figure $2 b$ ). A two-dimensional model of potential fields was developed for the regional dip profile along the refraction line GUMBO 2 (Figure 1) in order to test different OCB locations in the study area. The top part of the model (sedimentary section) was constrained by the reflection seismic (Figure 2a), while the depths to the crustal layers were based on the refraction data (Figure $2 b$ ).

\section{Integrated geophysical model}

The model consisted from the following layers:

- Water - the topmost layer with density of $1.03 \mathrm{~g} / \mathrm{cc}$ and zero magnetic susceptibility.

- $\quad$ Sedimentary section was divided into several layers based on the seismic data (Figure 2a). All sediments were assumed to be non-magnetic. The density values for sedimentary layers were chosen based on previous 


\section{Crustal distribution in the central Gulf of Mexico from an integrated geophysical analysis}

a. Seismic reflection for GulfSpan 2000
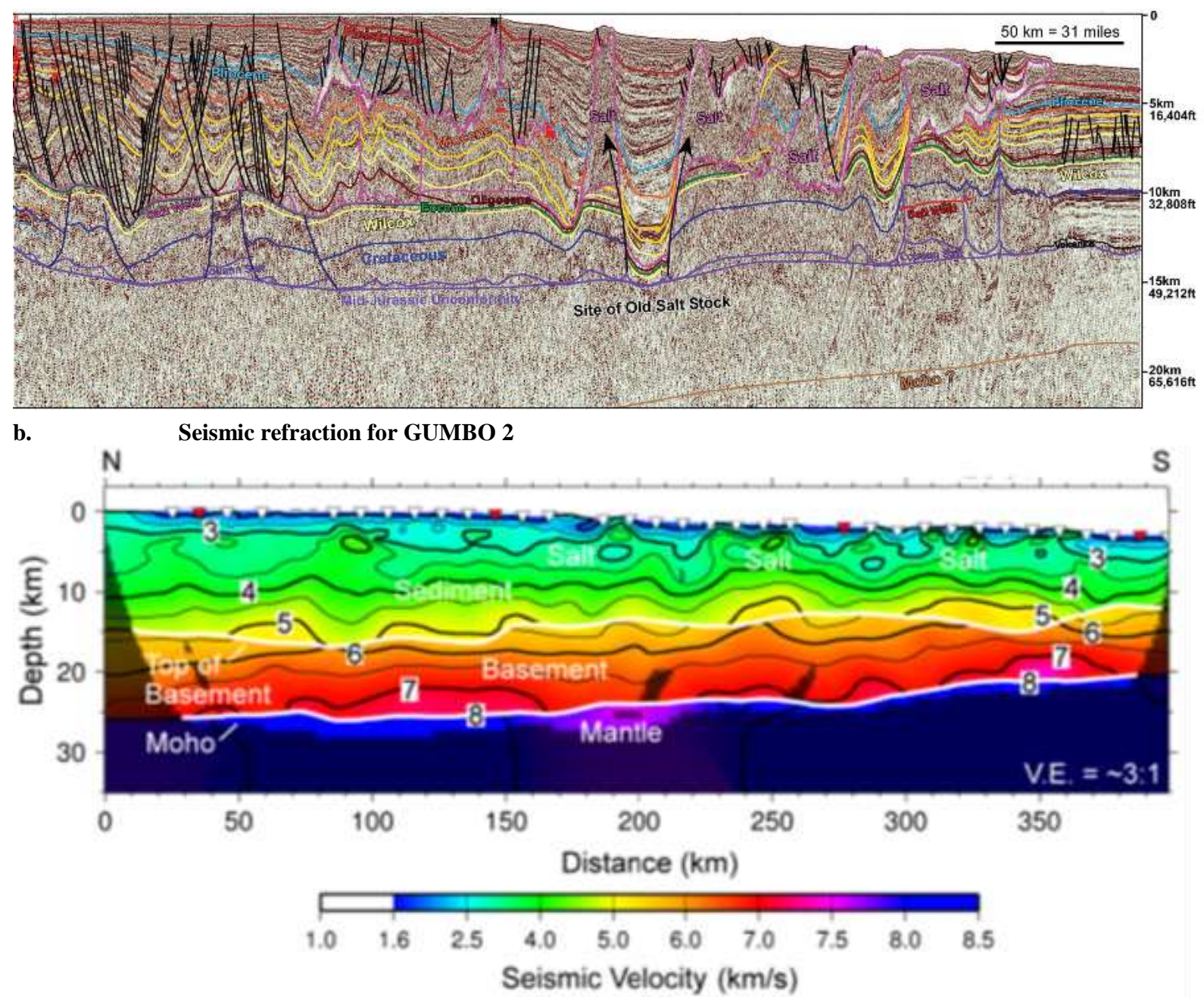

Figure 2: a. Seismic reflection image (Reverse Time Migrated) along the GulfSPAN line 2000 from Radovich et al., 2011. b. The results of the seismic refraction experiment along GUMBO 2 from Eddy, 2014; the colors are compressional seismic velocities. See the locations of both lines in Figure 1.

experience (Filina et al., 2015). The topmost sedimentary layer - Pleistocene - was assigned the density of $2.25 \mathrm{~g} / \mathrm{cc}$; the next one - Pliocene - was given a density of $2.35 \mathrm{~g} / \mathrm{cc}$; the Miocene and Paleogene were given 2.4 and $2.45 \mathrm{~g} / \mathrm{cc}$ respectively, while the density of the Mesozoic section of $2.55 \mathrm{~g} / \mathrm{cc}$ was assumed based on the carbonate rafts drilled in the GOM (Fiduk et al., 2014).

- $\quad$ The crust in the continental domain was divided into two layers; the upper crust was assigned the density of $2.75 \mathrm{~g} / \mathrm{cc}$ based on the results of the only basement penetration in the GOM (DSDP Leg 77, Volume LXXVII), and magnetic susceptibility of $250 \cdot 10^{-6}$ [SI]. The lower continental crust was assumed to have density of $2.9 \mathrm{~g} / \mathrm{cc}$
(Christensen and Mooney, 1995) and magnetic susceptibility of $500 \cdot 10^{-6}[\mathrm{SI}]$.

- The crust in oceanic domain was also assumed to be composed of two layers: the top oceanic layer (usually referred as layer 2) of basaltic composition was given a density of $2.65 \mathrm{~g} / \mathrm{cc}$ based on Carlson and Herrick (1990), and magnetic susceptibility of $1000 \cdot 10^{-6}$ [SI]. The bottom oceanic layer composed of gabbro (layer 3 ), was assumed to have density of $2.95 \mathrm{~g} / \mathrm{cc}$ (Carlson and Herrick, 1990) and magnetic susceptibility of $7000 \cdot 10^{-6}[\mathrm{SI}]$.

- The deepest layer - mantle - was given a density of $3.3 \mathrm{~g} / \mathrm{cc}$ and zero magnetic susceptibility. 


\section{Crustal distribution in the central Gulf of Mexico from an integrated geophysical analysis}

The geophysical modeling was performed via yam-2 module of the GM360 potential fields software.

\section{Results}

The preferred potential fields model is shown in Figure 3. In this model, the OCB was placed at the range $350 \mathrm{~km}$ near the Sigsbee Escarpment. Eddy (2014) defines the OCB along GUMBO2 line in the range of 320 to $350 \mathrm{~km}$, where the crustal thickness changes from $\sim 10 \mathrm{~km}$ to $\sim 7 \mathrm{~km}$ (the thickness of normal oceanic crust). The magnetic data show several distinct anomalies at the ranges of $100-150 \mathrm{~km}$ and $250-300 \mathrm{~km}$ (Figure 3). These are coincident with the regions of the high seismic velocities in GUMBO 2 profile (Figure $2 b$ ). These regions with elevated seismic velocities were interpreted as magmatic intrusive bodies that were emplaced in the lower continental crust during the rifting stage. The similar high-velocity intrusive body was also outlined at the base of the lower continental crust of the profile GUMBO 3 (Eddy, 2014). This is also consistent with the interpretation for the LithoSPAN line (see location in Figure 1), although the high-velocity intrusion for that line is found rather shallower in the section - at the top of the lower continental crustal unit near the OCB (Makris et al., 2015). In order to match the observed magnetic anomalies, the magnetic susceptibility of these intrusive bodies should be $7000 \cdot 10^{-6}[\mathrm{SI}]$, which is within the possible range for mafic igneous rocks (Hunt et al., 1995). In our preferred model, this value appears to be the same as magnetic susceptibility of the oceanic layer 3 .

\section{Discussion}

It is well known that the solution to the inverse problem of potential fields is not unique. In our model, the depths to the layers are constrained by seismic data (Figure 2), and are fixed during the modeling process. Thus, the physical properties and the OCB location are the only two "knobs" that can be used to obtain the desirable fit between observed and calculated anomalies. The densities of sedimentary section are more or less constrained (Filina et al., 2015), as well as the density of the upper crust (basement penetration in the GOM, although is far away of the study area). The layers that do not have any well penetrations in the GOM, so their physical properties must be assumed, are: lower continental crust, two oceanic crustal layers and the mantle. The published physical properties for these layers were used (Christensen and Mooney, 1995, Hunt et al., 1995, Carlson and Herrick, 1990).

The model shown in the Figure 3 suggests the OCB location far away to the south from the ones suggested by all tectonic models shown in Figure 1. The alternative OCB location (at the range of $190 \mathrm{~km}$ ) suggested by Nguen and Mann (2016) was also tested. For this alternative model the gravity fit remains reasonable because the decrease in density between the upper continental crust $(2.75 \mathrm{~g} / \mathrm{cc})$ to oceanic layer 2
$(2.65 \mathrm{~g} / \mathrm{cc})$ is somewhat compensated by the density increase from lower continental crust $(2.9 \mathrm{~g} / \mathrm{cc})$ to oceanic layer 3 $(2.95 \mathrm{~g} / \mathrm{cc})$. In order to maintain the fit between observed and calculated magnetic anomaly, the magnetic susceptibility of the oceanic crust must decrease from $7000 \cdot 10^{-6}[\mathrm{SI}]$ for the preferred model (Figure 3 ) to zero for the alternative one. Since the depths to the layers are constrained by refraction data, the shift in the OCB location to the north makes the assumed oceanic crust it the middle of the line to be 10 to $11 \mathrm{~km}$ thick, which is thicker than normal oceanic crust.

The disputed region is in the range between 190 and $350 \mathrm{~km}$ along the profile. The seismic velocities of the crust in this range are 5 to $6.5 \mathrm{~km} / \mathrm{s}$ for the upper layer and 6.5 to $7 \mathrm{~km} / \mathrm{s}$ for the lower one. These seismic velocities may be assigned to both oceanic and continental crustal units, and it is not possible to discriminate between these domains just on the seismic velocities. The gravity and magnetics also do not offer a unique distinction. The crustal thickness of $10 \mathrm{~km}$ makes the hypothesis of continental affiliation in the disputed region to be preferable. However, the thicker oceanic crust has been recorded in the GOM along the GUMBO 3 line, although the seismic velocities for oceanic domain of GUMBO 3 are much higher ( 6 to $7 \mathrm{~km} / \mathrm{s}$ for the upper crust, and exceeding $7 \mathrm{~km} / \mathrm{s}$ for the lower one).

One more argument toward the continental nature of the crust in the central GOM is the presence of the well-known prolific petroleum system over that region (Whaley, 2006, Dribus, 2008), indicating warm enough conditions for the sedimentary section within the basin to mature the source rock and generate hydrocarbons. Since the continental crust produces significantly more heat than oceanic one, the existence of extended hydrocarbon system would also lean towards the continental hypothesis. However, the working petroleum system can be developed over the oceanic crust (Rajmon and Egorov, 2015), although up to date only a few examples of such settings are known. Thus, the presence of petroleum system also does not allow the unique distinction between the two crustal domains as well.

Another way to discriminate between continental and oceanic domains is to examine the $\mathrm{Vp} / \mathrm{Vs}$ ratio for the crustal units (Christensen, 1996). This analysis was performed for the LithoSPAN line (Makris et al., 2015) and for GUMBO lines 3 and 4 (Duncan, 2013). The $\mathrm{Vp} / \mathrm{Vs}$ ratio for the LithoSPAN profile undoubtedly placed the OCB near the Sigsbee Escarpment (Figure 1, Makris et al., 2015). The continental domain in the LithoSPAN has the crustal thickness of $10 \mathrm{~km}$ and $\mathrm{Vp} / \mathrm{Vs}$ ratio of 1.75 , while the oceanic one has the normal crustal thickness of $6.5 \mathrm{~km}$ and $\mathrm{Vp} / \mathrm{Vs}$ ratio of 1.86 (Makris et al., 2015). Unfortunately, no Vs values are reported for GUMBO2 line up to date, so the question about the nature of the crust in the central part of the northern GOM is still open. 


\section{Crustal distribution in the central Gulf of Mexico from an integrated geophysical analysis}

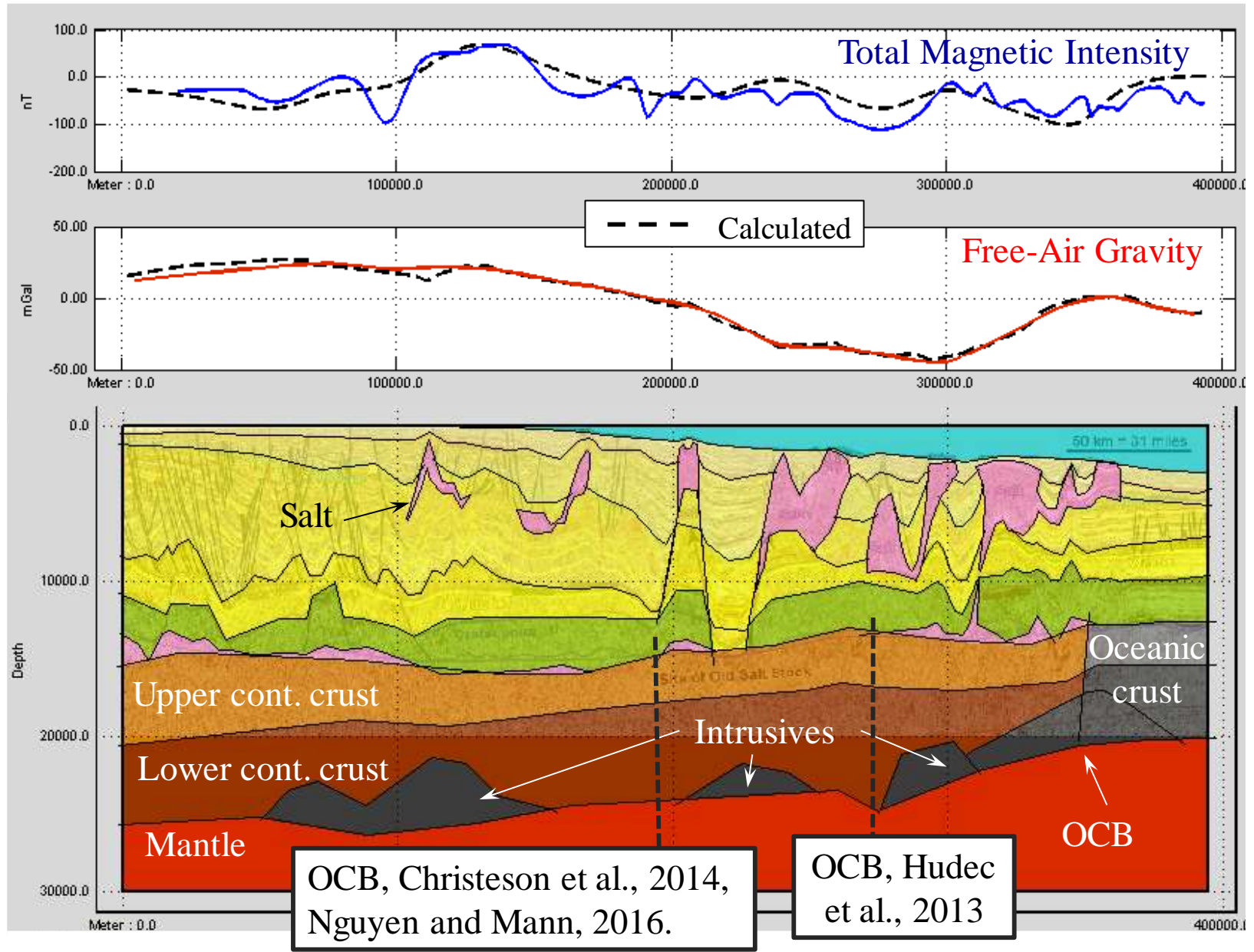

Figure 3: The preferred potential fields model. The top two panels show the fit in potential fields; the observed data are in solid lines, the calculated response due to the model at the bottom panel is shown as a black dashed line. The sedimentary section in this model is constrained by the reflection seismic (Radovich et al., 2011, Figure 2 a), while the crustal structures are from GUMBO 2 (Eddy, 2014, Figure 2 b). The physical properties assigned to the layers are given in the text. This model agrees with the interpretation of Eddy, 2014 that the OCB is located near the range of $350 \mathrm{~km}$ along this line. The two alternative OCB locations from published model are shown. The alternative OCB at the range of $190 \mathrm{~km}$ (as in Cristeson et al., 2014 and in Nquyen and Mann, 2016) was also tested (see the text).

\section{Conclusions}

The central part of the northern GOM is the region of a major disagreement between published tectonic models. The integrated geophysical analysis was performed along GUMBO 2 profile to study the nature of the crust in the disputed area. The preferred model suggests thinned and intruded continental crust for most of the line with the OCB near the Sigsbee Escarpment. This result agrees with the interpretation along the adjacent refraction profile LithoSPAN that has confirmed continental crustal affiliation based on the $\mathrm{Vp} / \mathrm{Vs}$ ratio. Nevertheless, the alternative model with the OCB far to the north of the Sigsbee Escarpment also fits both gravity and magnetic data, although the assumed oceanic crust is thicker than normal. While this alternative model is considered to be less likely, it still cannot be ruled out. The way to distinguish between the two crustal domains is to analyze the $\mathrm{Vp} / \mathrm{Vs}$ ratio. However, no Vs data for GUMBO 2 are publically available at this time. 


\section{Crustal distribution in the central Gulf of Mexico from an integrated geophysical analysis}

\section{References}

Bankey V.et al, 2002, Digital data grids for the magnetic anomaly map of North America, US Geological Survey Open-File Report 02-414

Carlson, R. L., and C. N. Herrick, 1990, Densities and porosities in the oceanic crust and their variations with depth and age, Journal of Geophysical Researches, v. 95(B6), pp. 9153-9170

Christensen, N. and W. Mooney, 1995, Seismic velocity structure and composition of the continental crust: A global view, Journal of Geophysical Research Atmospheres, v. 100, pp. 9761-9788.

Christensen, N., 1996, Poisson's ratio and crustal seismology, Journal of Geophysical Research, v. 101(B2), pp. $3139-3156$

Christeson, G. L., H. J. A. Van Avendonk, I. O. Norton, J. W. Snedden, D. R. Eddy, G. G. Karner and C. A. Johnson, 2014, Deep crustal structure in the eastern Gulf of Mexico, Journal of Geophysical Research: Solid Earth, v.119, pp. 6782-6801

DSDP Volume LXXVII, doi:10.2973/dsdp.proc.77.1984

Dribus J.R., Jackson, M. and K. Kapoor, 2008, The Prize Beneath the Salt, Oilfield Review, v. 20, n. 3, pp. 4-17

Duncan, M., 2013, The Northeastern Gulf of Mexico: Volcanic or Passive Margin? Seismic Implications of the Gulf of Mexico Basin Opening Project, M.S. Thesis, the University of Texas at Austin.

Eddy, D., 2014, Mesozoic rifting along the eastern seaboard of North America: insights from the seismic velocity structure of the Newfoundland margin and the northern Gulf of Mexico, M.S. Thesis, the University of Texas at Austin.

Fiduk, C., M. Clippard, S. Power, V. Robertson, L. Rodriguez, O. Ajose, D. Fernandez, D. Smith, 2014, Origin, Transportation, and Deformation of Mesozoic Carbonate Rafts in the Northern Gulf of Mexico, Gulf Coast Association of Geological Societies Transactions, v. 64, p. 689.

Filina, I., Delebo, N., Mohapatra, G., Coble, C., Harris, G., Layman, J., Strickler, M. and Blangy, J.P., 2015. Integration of seismic and gravity data-A case study from the western Gulf of Mexico. Interpretation, v. 3, n. 4, pp.SAC99SAC106

Hudec M. R., M.P. A. Jackson, and F. J. Peel, 2013 Influence of deep Louann structure on the evolution of the northern Gulf of Mexico, AAPG Bulletin, v. 97, no. 10, pp.1711-1735

Hunt, C. P., Moskowitz, B. M. and S. K. Banerjee, 1995, Magnetic Properties of Rocks and Minerals, Classification of Rocks and Their Abundances on the Earth (3-1), p. 189.

Kneller, E. A., and C. A. Johnson, 2011, Plate kinematics of the Gulf of Mexico based on integrated observations from the Central and South Atlantic, Gulf Coast Association of Geological Societies Transactions, v. 61, p. 283-299

Makris, J., 2015, Results of the LithoSPAN experiment: Presented at the ION GXT SPAN workshop.

Nguyen, L. C. and P. Mann, 2016, Gravity and magnetic constraints on the Jurassic opening of the oceanic Gulf of Mexico and the location and tectonic history of the Western Main transform fault along the eastern continental margin of Mexico, Interpretation, v. 4, no. 1, pp. SC23-SC33

Pindell J.L. and Keenan K., 2009, Tectonic evolution of the Gulf of Mexico, Caribbean and northern South America in the mantle reference frame, Geological Society of London, v. 328, pp. $1-55$

Radovich, B., B. Horn, P. Nuttall and A. McGrail, 2011, A Unique Basin-Wide Dataset, GeoExPro, v. 8, no.2, p.36

Rajmon, D. and V. Egorov, 2015, An Overlooked Petroleum System: Is it possible to generate hydrocarbons over the oceanic crust? GeoExPro, v. 12, n.6, p.12

Sandwell D.T., R. D. Muller, W. Smith, E. Garcia and R. Francis, 2014, New global marine gravity model from CryoSat-2 and Jason-1 reveals buried tectonic structure, Science, v. 346, pp. 65-67

Whaley J., 2006, Huge Potential Still Waiting in the Gulf of Mexico, GeoExPro,v. 3, n. 4, pp. 14-24 